\title{
Komunikasi Informasi Edukasi Penyakit Jantung Pada Remaja Obesitas
}

\author{
Bety Semara Lakhsmi ${ }^{1}$, Fadjar Herianto ${ }^{1}$ \\ 1Universitas Muhammadiyah Prof. DR. HAMKA Jl. Tanah Merdeka, Jakarta Timur, Indonesia \\ Email: betysemaralakhsmi@yahoo.com
}

\begin{abstract}
Abstrak
Gejala awal pada remaja yang menderita penyakit jantung sama dengan orang dewasa, antara lain nyeri pada dada, mengeluarkan keringat terutama telapang tangan, merasa lelah berlebihan, nafas berat, jantung berdebar-debar, sakit kepala, dan perut kembung. Penyakit jantung merupakan penyakit yang disebabkan oleh penyempitan pembuluh darah arteri/nadi. Konsumsi sayur dan buah-buahan yang mengandung antioksidan yang tinggi, dapat mencegah terjadinya stress oksidatif, yang merupakan salah satu penyebab timbulnya plak pada pembuluh darah. Namun kenyataan yang ada $80 \%$ remaja tidak mengkonsumsi sayur dan buah secara rutin setiap hari, dan lebih banyak mengkonsumsi makanan siap saji yang mengandung kadar lemak tinggi. Obesitas terjadi pada remaja dengan jumlah semakin meningkat tiap tahun. Obesitas dapat merubah metabolisme tubuh, dimana terjadi kemunduran pengolahan lemak dalam tubuh, sehingga penimbunan lemak semakin tinggi. Obesitas central, adalah penimbunan lemak di perut, dimana lemak di perut lebih berisiko membentuk plak di pembuluh darah, dan berakibat penyumbatan. Pemberikan Komunikasi Iinformasi Edukasi (KIE) tentang pencegahan penyakit jantung pada remaja menjadi suatu hal yang penting. Hal ini yang melatarbelakangi kegiatan pengabdian masyarakat ini perlu dilakukan. Pencegahan penyakit jantung harus dilakukan sejak dini saat usia muda. adapun metode yang dilaksanakan 1) mencari dan menemui mahasiswa memiliki obesitas dan overweight (35 mahasiswa), 2) pengisian biodata dan mengukur berat badan, dan 3) pembekalan pengetahuan materi gaya hidup sehat. Kemudian dapat disimpulkan: 1) Penyakit jantung sangat berkaitan dengan gaya hidup dimana perilaku hidup sehat seperti menjaga berat badan, konsumsi sayur dan buah, aktifitas fisik dan rutin berolah raga dapat menurunkan risiko penyakit jantung, 2) Pencegahan penyakit jantung diupayakan melalui pengelolaan factor risiko yang dapat dimodifikasi termasuk salah satunya adalah obesitas. 3) Kegiatan Komunikasi Informasi dan Edukasi melalui media leaflet dapat dilakukan untuk remaja. Nilai satuan penukar ditampilkan dalam leaflet dapat dijadikan rujukan setiap membaca label pada kemasan makanan.
\end{abstract}

Kata kunci: komunikasi, Penyakit Jantung, Obesitas.

\begin{abstract}
Early symptoms of heart disease to teenagers almost the same as the adults. Those symptoms are chest pain, sweating especially to the hand, excessive tiredness, heavy breathing, palpitations, headaches, and flatulence. Heart disease is a disease caused by narrowing of the arteries/veins. Vegetables and fruits consumption that contain high antioxidants, can prevent the occurrence of oxidative stress, which is one cause of plaque on blood vessels. But the fact is there are $80 \%$ of teenagers consumed fast food that contains high fat. This unhealthy diet can escalate obesity to teenagers. In order to educate on the prevention of heart disease in adolescents, the community service presented coaching as for the steps were as followed: 1) found and met students with obesity and overweight (35 students), 2) filled in biodata and weight measuring, and 3) providing knowledge of healthy lifestyle material. As the result of this activity: 1) Heart disease is closely related to lifestyle; such as maintaining weight, healthy diets, physical activity and daily exercise can reduce the risk of heart disease, 2) Prevention of heart disease through the management of risk factors that can be modified eg obesity prevention 3 ) leaflets as heart disease media education for adolescents.
\end{abstract}

Keywords: healthy diet, heart disease

Format Sitasi: Lakhsmi, B.S. \& Herianto, F. (2017). Komunikasi Informasi Edukasi Penyakit Jantung pada Remaja Obesitas. Jurnal SOLMA, 07(1), 51-58.

Revisi: 24-01-2018; Diterima: 20-02-2018; Diterbitkan: 07-04-2018. 


\section{PENDAHULUAN}

Penyakit jantung ada beberapa macam, antara lain penyakit jantung coroner, juga disebut penyakit arteri koroner (CAD), penyakit jantung iskemik (IHD), atau penyakit jantung aterosklerotik, dan gangguan otot jantung karena hasil akhir dari akumulasi plak ateromatosa dalam dinding-dinding arteri yang memasok darah ke miokardium (otot jantung) (Manitoba Centre for Health Policy, 2013). Jantung adalah sebuah organ berotot dengan empat ruang yang terletak di rongga dada, di bawah perlindungan tulang iga, sedikit ke sebelah kiri sternum. Jantung terdapat disebuah kantung longgar berisi cairan disebut perikardium. Keempat ruang jantung tersebut adalah atrium kiri dan kanan serta ventrikel kiri dan kanan. Atrium terletak di atas ventrikel dan saling berdampingan. Atrium dan ventrikel dipisahkan satu dari yang lain oleh katup satu arah. Sisi kiri dan kanan jantung dipisahkan oleh sebuah dinding jaringan yang disebut septum. Dalam keadaan normal tidak terjadi pencampuran darah antara kedua atrium kecuali pada masa janin, dan tidak pernah terjadi pencampuran darah antara kedua ventrikel pada jantung yang sehat. Semua ruang tersebut dikelilingi oleh jaringan ikat. Jantung mendapat suplai persarafan yang halus. Dua sirkulasi sistem kardiovaskuler yaitu sisi kiri jantung memompa darah ke seluruh sel tubuh kecuali sel-sel yang berperan dalam pertukaran gas di paru. Ini disebut sirkulasi sistemik. Sisi kanan jantung memompa darah ke paru untuk mendapat oksigen. Ini disebut sirkulasi paru (pulmoner).

Nurhidayat (2010), menemukan ada hubungan penyakit kardiovaskuler pada remaja dengan obesitas, dimana remaja yang obesitas 5,784 kali berisiko menderita penyakit kardiovaskuler daripada yang tidak obesitas. Dan apada analisis multivariate, obesitas menjadi variable dominan penyebab penyakit kardiovaskuler pada remaja.

Gejala awal pada remaja yang menderita penyakit jantung sama dengan orang dewasa, antara lain nyeri pada dada, mengeluarkan keringat terutama telapang tangan, merasa lelah berlebihan, nafas berat, jantung berdebar-debar, sakit kepala, dan perut kembung. Penyakit jantung merupakan penyakit yang disebabkan oleh penyempitan pembuluh darah arteri/nadi. Penyempitan dan penyumbatan disebabkan adanya plak di pembuluh darah, salah satunya dikarenakan perilaku konsumsi makanan berlemak tinggi seperti hamburger, pizza hut, ayam kentuki dan lainnya (Sumartono, 1995).

Konsumsi sayur dan buah-buahan yang mengandung antioksidan yang tinggi, dapat mencegah terjadinya stress oksidatif, yang merupakan salah satu penyebab timbulnya plak 
pada pembuluh darah. Namun kenyataan yang ada $80 \%$ remaja tidak mengkonsumsi sayur dan buah secara rutin setiap hari, dan lebih banyak mengkonsumsi makanan siap saji yang mengandung kadar lemak tinggi.

Obesitas terjadi pada remaja dengan jumlah semakin meningkat tiap tahun. Obesitas dapat merubah metabolisme tubuh, dimana terjadi kemunduran pengolahan lemak dalam tubuh, sehingga penimbunan lemak semakin tinggi. Obesitas central, adalah penimbunan lemak di perut, dimana lemak di perut lebih berisiko membentuk plak di pembuluh darah, dan berakibat penyumbatan.

Pemberikan Komunikasi Iinformasi Edukasi (KIE) tentang pencegahan penyakit jantung pada remaja menjadi suatu hal yang penting. Hal ini yang melatarbelakangi kegiatan pengabdian masyarakat ini perlu dilakukan. Pencegahan penyakit jantung harus dilakukan sejak dini saat usia muda.

\section{MASALAH}

Obesitas dan penyakit jantung, dikenal remaja sebagai hal yang tidak penting. Konsumsi makanan fast food yang memiliki kadar $\mathrm{Na}$, lemak jenuh, dan kholesterol tinggi merupakan faktor risiko peningkatan berat badan yang berakibat obesitas. Pola hidup remaja saat ini menyukai minuman manis berkadar gula tinggi, kurang aktifitas fisik dan kurang olahraga sudah menjadi kebiasaan sehari-hari. Pengetahuan yang rendah tentang bahaya obesitas, sulitnya menurunkan berat badan pada obesitas, dan stigma obesitas adalah keturunan menjadi kendala dalam pengontrolan berat badan. Sebagian besar mahasiswa punya persepsi, penyakit jantung merupakan penyakit lansia yang tidak mungkin diderita oleh remaja.

\section{METODE PELAKSANAAN}

Tim pengabdian masyarakat mencoba pemberian program pelatihan pembuatan informasi edukasi penyakit jantung pada remaja obesitas

\section{a. Tahap persiapan}

Kegiatan ini diawali dengan pengurusan izin ke kampus B FIKES UHAMKA Universitas Muhammadiyah Prof Dr. HAMKA. Pengurusan izin dengan penyerahan surat izin kepada Pimpinan FIKES UHAMKA, sekaligus menyampaikan maksud dan tujuan kegiatan pengabdian masyarakat yang akan dilaksanakan di ruang kelas. Persiapan sarana dan prasarana juga dilakukan. 
Selanjutnya, tim pelaksana pengabdian masyarakat mencari dan menemui mahasiswa yang memiliki berat badan obesitas dan overwieght untuk menjadi calon peserta kegiatan pengabdian masyarakat . Target jumlah peserta adalah 35 orang mahasiswa obesitas maupun overweight.

\section{b. Tahap Pelaksanaan}

Pelaksanaan dimulai dengan mengisi biodata peserta berikut data berat badan dan tinggi badan. Tim juga menyediakan alat ukur berat badan bila ada mahasiswa yang lupa atau ragu-ragu berapa berat badannya.

\section{c. Evaluasi}

Evaluasi dilaksanakan dengan meminta tanggapan dari peserta mengenai kesesuaian materi, penyampaian narasumber, manfaat kegiatan, format acara, dan saran serta perbaikan

\section{PEMBAHASAN}

Pengabdiaan masyarakat berjudul "IbM Komunikasi Informasi Edukasi Penyakit Jantung Pada Remaja Obesitas" di kampus B Universitas Muhammadiyah Prof. Dr. HAMKA jalan Limau II, Kebayoran Baru, Jakarta Selatan telah selesai dilaksanakan pada hari Rabu, tanggal 5 April 2017. Jumlah peserta yang ditargetkan 35 orang mencapai 51 orang dengan kategori IMT berdasarkan perhitungan berat badan dan tinggi badan sebagai berikut:

Tabel 1. Indeks Masa Tubuh Peserta Berdasar Standar Kemenkes

\begin{tabular}{|c|l|c|c|}
\hline No & Kriteria & Jumlah & Persentase \\
\hline 1 & Kurus & 12 & 23,5 \\
\hline 2 & Normal & 26 & 50,9 \\
\hline 3 & Overweight & 3 & 6,0 \\
\hline 4 & Obesitas & 10 & 19,6 \\
\hline & Jumlah & 51 & $100 \%$ \\
\hline
\end{tabular}

Indeks Masa Tubuh (IMT) Standar Kemenkes:

Kategori Kurus $\quad:<18,5$

Kategori Normal $\quad: \geq 18,5-<24,9$

Kategori Overweight : $\geq 25,0-<27,0$ 
Kategori Obesitas $\quad: \geq 27,0$

Pengukuran Indeks Masa Tubuh dihitung berdasarkan berat badan dan tinggi badan dengan menggunakan rumus;

$$
\mathrm{IMT}=\text { Berat Badan/ Tinggi Badan }{ }^{2} \text { (dalam meter) }
$$

Peserta yang mempunyai IMT kategori obesitas sebanyak 10 orang atau 19,6\% dan kategori overweigkt sebanyak 3 orang atau $6 \%$. Seluruh peserta mengikuti presentasi materi yang diberikan oleh narasumber dengan penuh perhatian.

Obesitas adalah kelebihan lemak dalam tubuh, yang umumnya ditimbun dalam jaringan subkutan (bawah kulit), sekitar organ tubuh dan kadang terjadi perluasan ke dalam jaringan organnya (Misnadierly, 2007). Menurut WHO Obesitas adalah penumpukan lemak yang berlebihan ataupun abnormal yang dapat mengganggu kesehatan.

Provinsi DKI Jakarta termasuk 5 Provinsi dengan prevalensi tertinggi diatas prevalensi nasional nomor 3 setelah Sulawesi Utara dan Gorontalo. Disusul kemudian KalimantanTimur dan Maluku Utara.

Berbagai macam factor penyebab obesitas diantaranya adalah:
a. Keturunan
b. Kelainan di hipotalamus yang mengatur rasa lapar
c. Hipotiroid
d. Makan berlebih
e. Kurang aktifitas
f. Jenis makanan Junk Food (Na, lemak jenuh, Cholesterol)
g. Pekerjaan banyak duduk
h. Emosi labil
i. Kemudahan transportasi
j. $\quad$ Sosial Gemuk $=$ makmur
k. Pria $<$ wanita 
Pola makan yang tidak seimbang antara asupan makanan dan aktifitas fisik, kurang gerak dan pengaruh emosi menjadi penyebab utama obesitas pada remaja. Saat ini obesitas merupakan wabah global di seluruh belahan dunia.

Obesitas mempunyai factor risiko timbulnya penyakit Diabetes, Aterosklerosis, Hipertensi, Penyakit Jantung Koroner, Stroke, Perlemakan organ, Osteoporosis, Osteo Arthrosis, Cedera, nyeri punggung, kelainan kulit, GERD, dan lain sebagainya. Faktor risiko timbulnya penyakit jantung salah satunya adalah obesitas. Faktor risiko yang lainnya adalah hipertensi, Diabetes Melitus, obesitas sentral, kurang aktifitas fisik, hiperkolesterol, dislipidemi, merokok, kopi, dan alkohol.

Berat badan yang sehat, normal, atau ideal (Healthy Weight) adalah berat badan yang bukan Underweight, bukan pula Overweight (Kegemukan) atau obesitas, berarti BMI 18,5 - 24,9. Lingkar pinggang dibawah $88 \mathrm{~cm}$ untuk wanita dan di bawah $102 \mathrm{~cm}$ untuk pria.

Serangan jantung terjadi bila pembuluh nadi koroner tersumbat total, sehingga menimbulkan kematian/nekrosis jaringan otot jantung yang diperdarahai. Ditandai dengan timbulnya gejala nyeri dada hebat, lamanya nyeri kadang-kadang sampai berjam-jam, sesak napas, mual,muntah, berkeringat, pucat, ketakutan, kehilangan kesadaran sampai kematian mendadak.

Pemeriksaan penunjang untuk mendeteksi secara dini penyakit jantung maupun faktor risikonya dapat dilakukan melalui pemeriksaan darah, Renal function and electrolytes, blood lipid profile, blood glucose, Electrocardiography (ECG), Echocardiogram maupun Uji Latih Jantung Beban (ULJB).

Cara menanggulangi obesitas membutuhkan motivasi yang tinggi, pengaturan pola makan, pola hidup sehat, terapi medis bahkan pembedahan bila diperlukan. Menjalani pola hidup sehat telah banyak terbukti dapat menurunkan tekanan darah, mengontrol gula darah dan secara umum sangat menguntungkan dalam menurunkan risiko penyakit kardiovaskular. 4 Pilar gizi seimbang yang perlu diperhatikan adalah:
a. Mengkonsumsi berbagai ragam jenis makanan;
b. Membiasakan perilaku hidup bersih;
c. Melakukan aktifitas fisik dan;
d. Mempertahankan dan memantau berat badan dalam batas normal.

Sedangkan pesan gizi seimbang adalah: 
a. Syukuri dan nikmati aneka-ragam makanan;

b. Banyak makan sayur dan buah;

c. Biasakan mengkonsumsi lauk pauk yang mengandung protein tinggi;

d. Biasakan mengkonsumsi aneka-ragam makanan pokok;

e. Btasi konsumsi makanan manis, asin dan berlemak;

f. Biasakanlah sarapan;

g. Biasakan minum air putih yang cukup dan aman;

h. Biasakan membaca label pada kemasan pangan;

i. Cuci tangan pakai sabun dengan air bersih mengalir;

j. Lakukan aktifitas fisik yang cukup dan pertahankan berat badan normal.

Kunci untuk menjaga berat badan normal adalah dengan intervensi diit dan aktifias fisik. Intervensi diit dilakukan dengan cara makan setidaknya 5-7 porsi buah dan sayuran perhari serta makan 25 - 30 gram serat perhari dari buah/sayur, roti, gandum, sereal, dan kacang-kacangan. Aktifitas fisik yang dianjurkan paling sedikit 150 menit dalam seminggu. Dengan latihan fisik tersebut di atas sudah dapat menurunkan berat badan 2-3 $\mathrm{kg}$.

Tips bagi remaja obesitas adalah "Love Your Body" dengan mencintai dan menjaga tubuh kita. Jangan mudah tergoda dengan kudapan keripik, coklat, gorengan dan kue kering. Hati-hati dengan minuman Jus dengan tambahan gula dan soft drink, serta gantilah cemilan dengan sayur dan buah.

\section{KESIMPULAN}

1. Respon kit jantung sangat berkaitan dengan gaya hidup dimana perilaku hidup sehat seperti menjaga berat badan, konsumsi sayur dan buah, aktifitas fisik dan rutin berolah raga dapat menurunkan risiko penyakit jantung.

2. Pencegahan penyakit jantung diupayakan melalui pengelolaan factor risiko yang dapat dimodifikasi termasuk salah satunya adalah obesitas.

3. Kegiatan Komunikasi Informasi dan Edukasi melalui media leaflet dapat dilakukan untuk remaja. Nilai satuan penukar ditampilkan dalam leaflet dapat dijadikan rujukan setiap membaca label pada kemasan makanan.

Diperlukan motivasi yang tinggi, intervensi diet dan aktifitas fisik atau olahraga rutin untuk dapat mencapai berat badan normal. 


\section{UCAPAN TERIMA KASIH}

Terima kasih kepada LPPM (Lembaga Penelitian dan Pengabdian Masyarakat) UHAMKA telah memberikan bantuan baik berupa materil maupun non materil sehingga kegiatan Komunikasi Informasi Edukasi Penyakit Jantung pada Remaja Obesitas dapat berjalan lancer dan bermanfaat bagi peserta khususnya.

Terima kasih tidak lupa kepada Pimpinan FIKES UHAMKA, sebagai mitra dalam kegitan dan membantu dalam memberikan izin sehingga tim dapat leluasa memberikan informasi dan pengabdian kepada mahasiswa di wilayah FIKES.

\section{DAFTAR PUSTAKA}

Nurhidayat S. 2010. Faktor Risiko Penyakit Kardiovaskuler pada Remaja di Ponorogo. http://eprints.umpo.ac.id/1295/1/Jurnal\%20Dunia\%20 Keperawatan\%20.pdf

Sumartono R.W. 1995. Pencegahan Penyakit Jantung Koroner di Indonesia. Jurnal Media Litbangkes Vol. 1 No.1

Cahyono, J. S. B. 2008. Gaya Hidup \& Penyakit Modern. Kanisius 